\title{
БЕЗОПАСНОСТЬ НА ВОДНОМ ТРАНСПОРТЕ: НОРМАТИВНО-ПРАВОВЫЕ ОСНОВАНИЯ
}

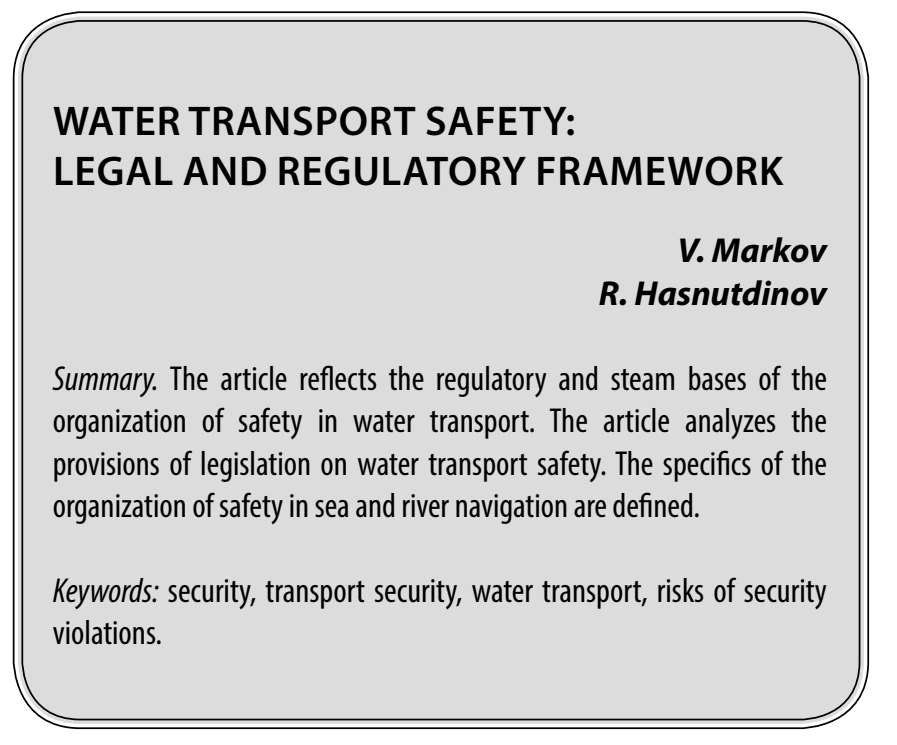

\section{Актуа^ьность}

B одный транспорт признается ключевым элементом российской транспортной системы. В отдельных регионах от водного транспорта зависит жизнеобеспечение. Среди всех видов водный транспорт признается наиболее безопасным и энергосберегающим. Вместе с тем износ производственных фондов отрасли морского и водного транспорта страны составляет более $60 \%$, что определяет риски и угрозы безопасности, одними из которых являются транспортные преступления. Установлено, что нарушение безопасности на водном транспорте нередко коррелирует с безответственностью и жаждой наживы у недобросовестных предпринимателей. Однако, не все так однозначно анализ материалов практических конференций указывает на значительное число административных барьеров, вызванных требованиями к безопасности, обоснованными в законодательстве, далеком совершенства, которое не учитывает отраслевую специфику водного транспорта.

В рамках настоящей публикации целью статьи является анализ актуальных проблем обеспечения безопасности на водном транспорте.

\section{Метолика}

В процессе написания статьи применялись методы теоретического анализа литературы и положений действующего законодательства, регулирующего вопросы
Марков Владимир Петрович

Д.ю.н., дочент, ФГБОУ ВО «Самарский государственный экономический университет»

sf-vguvt@mail.ru

Хаснутдинов Ринат Рафаильевачч

К.ю.н., дочент, ФГБОУВО «Самарский государственный экономический университет»

Аннотация. Статья отражает нормативно-паровые основания организации безопасности на водном транспорте. Дается анализ положений законодательства о безопасности на водном транспорте. Определена специфика организации безопасности в морском и речном судоходстве.

Ключевые слова: безопасность, транспортная безопасность, водный транспорт, риски нарушения безопасности.

обеспечения транспортной безопасности на водном транспорте.

\section{Основное изложение статьи}

Обеспечение безопасности на водном транспорте является комплексной междисциплинарной задачей, решение которой требует должного правового обеспечения. По данному моменту накоплено немало вопросов теории и практики, решение которых тормозится.

В частности, Федеральный закон № 390-Ф3 «О безопасности» (ред.6.02.2020) не дает содержательной интерпретации о том, что такое «безопасность». Однако, законодатель описывает содержательные аспекты деятельности по обеспечению безопасности, выделяя в ее составе прогностическую, диагностическую, оценивающую функции, выполнение которых позволяет определять направления политики государства в данном ключе. Таким образом, законодатель никак не обозначил в профильном законе необходимость обеспечения безопасности на водном транспорте.

Большую конкретизацию в отношении того, как должна быть организована безопасность на водном транспорте, дают положения Федерального закона № 16-Ф3 «О транспортной безопасности» (ред. 2.12.2019)[4]. Так, статья 1 этого закона отражает основные понятия, в числе которых значатся дефиниции, обеспечивающие категоризацию транспортной безопасности и объектов 
транспортной инфраструктуры: транспортная безопасность, транспортная инфраструктура, зона и уровни безопасности. Важно, что в статье 1 данного закона дается перечень водных объектов и средств водного транспорта, безопасность которых необходимо обеспечивать.

Таким образом, основываясь на нормах закона, транспортную безопасность на водном транспорте законодатель предлагает рассматривать, на общих основаниях как состояние объектов транспортной инфраструктуры и транспортных средств от незаконного вмешательства. Следует обратить внимание, что безопасность на водном транспорте относится к отраслевому виду транспортной безопасности, то есть данное понятие соотносится с термином «транспортная безопасность» как общее и частное. Поэтому сформулированное в законе понятие имеет узкую трактовку.

Целый ряд аспектов безопасности на водном транспорте находит отражение в Кодексе внутреннего водного транспорта РФ № 24-Ф3 (ред. от 2.08.2019)[1]. Обращение к данному федеральному закону не позволяет в нем найти термин «транспортная безопасность». В основном безопасность в Главе 6 этого закона связывается с безопасной эксплуатацией водного транспорта, безопасным судоходством и экологической безопасностью. Для этих целей в статье 41 Кодекса за государственными и негосударственными лоцманскими организациями, обеспечивающими безопасность прохождения судов по внутренним водным путям.

Во избежание иных рисков Кодекс внутреннего водного транспорта РФ № 24-Ф3 (ред. от 2.08.2019) предъявляет повышенные требования к экипажу судов. Статья 27 Кодекса в числе требований к безопасности судоходства определяет обязательное прохождение экипажем медицинского осмотра, определяет запрет на употребление наркотических, психоактивных веществ и административную ответственность за нарушение данных требований.

Повышенные требования Кодекс предъявляет к безопасности перевозок опасных грузов посредством водного транспорта на территории страны. Статья 86 Кодекса определяет, что предметом обеспечения безопасности на внутреннем водном транспорте выступает жизнь и здоровье людей, сохранение материальных ценностей, сохранение экологии. Определяются правила транспортного взаимодействия грузоперевозчика, грузоотправителя и грузополучателя в случае перевозки опасных грузов.

Отдельно регулируются вопросы безопасности перевозки воинских грузов с помощью морского и водного транспорта, представляющих опасность для жизни лю- дей и экологии. В частности, в Приказ Министра обороны РФ от 23.08.1997 № 321 «Об охране и сопровождении воинских грузов при их перевозке железнодорожным, морским и речным транспортом» определяются требования к безопасности личного состава караула, обеспечивающего охрану груза, перевозимого водным транспортом[3].Таким образом, документ отражает специфику перевозки воинских грузов и особенности организации транспортной безопасности водного транспорта.

Не необходимость обеспечения безопасности морского судоходства и торгового мореплавания указывают нормы «Кодекса торгового мореплавания Российской Федерации» № 81-Ф3 (ред. от 01.03.2020)[2]. При этом, также как и в других документах, Кодекс не отражает основные понятия, в числе которых транспортная безопасность. Акцент делается главным образом на безопасности торгового мореплавания и имущественных отношений. Статья 60 Кодекса определяет необходимость обеспечения со стороны судовладельца безопасных условий труда на корабле. В компетенцию капитана корабля статья 61 Кодекса относит безопасность плавания судна, и предотвращение вреда судну и экипажу, грузу, в том числе и в случаях военной опасности. Статья 67 Кодекса определяет компетенцию капитана по отстранению подчиненных от выполнения обязанностей в случае создания угрозы безопасности судна и находящимся на нем людям. В целях обеспечения безопасности морского транспорта статья 69 Кодекса определяет полномочия капитана судна по проведению неотложных следственных действий и возбуждения уголовного дела во время морского плавания. Отдельно статья 69.1 определяет полномочия капитана по передаче органам, имеющим соответствующие полномочия, лица в случае, если есть основания полагать, что лицо совершило преступное действие против безопасности морского судоходства. В случае, если капитан не может выполнять перечисленные обязанности, их выполняет старший помощник капитана судна. Статьей 84 Кодекса определяется право капитана морского порта налагать административный штраф за нарушение порядка в порту и безопасности мореплавания. Глава 6 Кодекса определяет роль морских лоцманов в обеспечении безопасности морского судоходства.

Таким образом, анализ положений действующего законодательства, регламентирующего вопросы обеспечения безопасности на водном транспорте, позволяет отметить множество нерешенных вопросов и необходимость дальнейшего совершенствования законодательства. Требуют проработки основные понятия отраслей безопасности на морском и водном транспорте. Установлено, что в федеральном законодательстве основное внимание уделяется содержательным аспектам отраслевых видов безопасности. 


\section{ЛИТЕРАТУРА}

1. «Кодекс внутреннего водного транспорта Российской Федерации» от 07.03.2001 N24-Ф3 (ред. от 02.08.2019) // СПС Консультант. - [Электронный ресурс].— Режим доступа: http://www.consultant.ru/document/ (дата обращения: 12.03.2020).

2. «Кодекс торгового мореплавания Российской Федерации» 0т 30.04.1999 N81-Ф3 (ред. от 01.03.2020)// СПС Консультант.— [Электронный ресурс].— Режим доступа: http://www.consultant.ru/document/ (дата обращения: 12.03.2020).

3. Приказ Министра обороны РФ от 23.08.1997 N321 «06 охране и сопровождении воинских грузов при их перевозке железнодорожным, морским и речным транспортом»// СПС Консультант. — -Электронный ресурс]. — Режим доступа: http://www.consultant.ru/document/ (дата 0бращения: 12.03.2020).

4. Федеральный закон от 09.02.2007 № 16-Ф3 (ред. от 02.12.2019) «0 транспортной безопасности» // СПС Консультант.— [Электронный ресурс].— Режим доступа: http://www.consultant.ru/ (дата обращения: 12.03.2020).

○ Марков Владимир Петрович ( sf-vguvt@mail.ru ), Хаснутдинов Ринат Рафаильеваич.

Журнал «Современная наука: актуальные проблемы теории и практики»

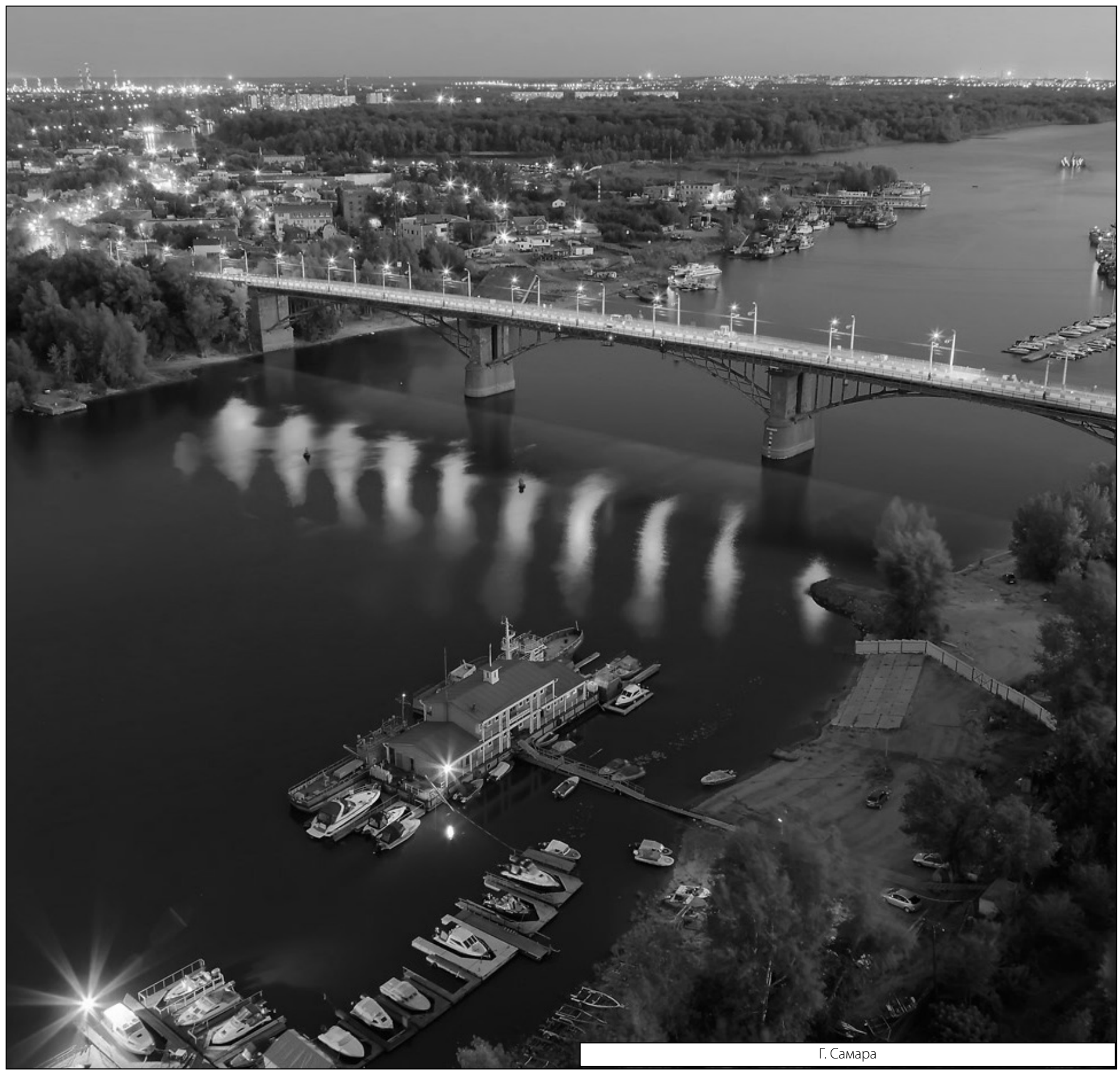

